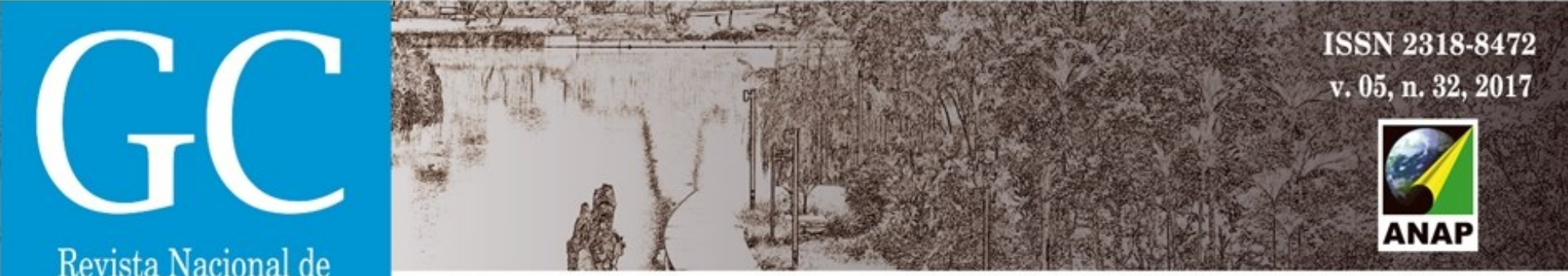

\title{
TERRITÓRIOS DOS GÊNEROS \\ A Experiência Urbana da Cidade as margens da dicotomia Sexual
}

\author{
GENDER TERRITORIES \\ The Urban City Experience the margins of the Sexual dichotomy \\ TERRITORIOS DE LOS GÉNEROS \\ La Experiencia Urbana de la Ciudad los márgenes de la dicotomía Sexual
}

Ricardo Mingareli Del Valle Mestrando do Programa de pós-graduação stricto sensu em Arquitetura e Urbanismo, USJT ricardo.delvalle@gmail.com

Fernando Guillermo Vázquez Ramos Professor Adjunto do Programa de pós-graduação stricto sensu em Arquitetura e Urbanismo, USJT fernando@fv.arq.br 


\section{RESUMO}

Kevin Lynch (1999) define a essência da experimentação de cidade com o termo "Legibilidade", que caracteriza a imagem da cidade pelas ações produzidas através das experimentações urbanas vivenciadas na cidade, compondo seu sistema organizacional. Este trabalho pretende possibilitar uma leitura de como estas experiências são geradas através das experimentações sensoriais de visão, audição, olfato e tato, estipuladas por Edward T. Hall (2005), que permite a concepção efetiva da imagem especifica do ambiente, incorporando assim sua legibilidade.

Quando estas experimentações são categorizadas pela distinção de gêneros, elas proporcionam uma visão diferenciada entre homens e mulheres, como apontados nos estudos de Beatriz Preciado (2010), podendo assim classificar o ambiente pelo seu uso específico, decorrente das experimentações sensoriais humanas e urbanas.

Este trabalho apresenta uma reflexão sobre o contexto social segregado pela sexualidade, criando uma fissura classificatória de cidade que categoriza a quem o espaço urbano é destinado.

Tendo estereotipado o espaço masculino e feminino, o intuito deste trabalho estará na identificação da composição simbólica construída pelo emaranhado de experiências sociais segregadas pelos gêneros que compõe as histórias territoriais e cotidianas do espaço, criando experiências, ainda que completamente, distintas entre homens e mulheres no espaço urbano apropriado.

PALAVRAS-CHAVE Legibilidade, Segregação, Territorialidade.

\section{ABSTRACT}

Kevin Lynch (1999) defines the essence of city experimentation with the term "Legibility", which characterizes the image of the city by actions produced through the urban experimentations experienced in the city, composing its organizational system. This work intends to allow a reading of how these experiences are generated through the sensory experiments of vision, hearing, smell and touch stipulated by Edward T. Hall (2005), that allows the effective conception of the specific image of the environment, thus incorporating its readability .

When these experiments are categorized by gender distinction, they provide a differentiated view of men and women, as pointed out in the studies of Beatriz Preciado (2010), and can thus classify the environment by its specific use, resulting from human and urban sensory experiments.

This work presents a reflection about the social context segregated by sexuality, creating a classificatory fissure of city that categorizes to whom the urban space is destined.

Having stereotyped the masculine and feminine space, the aim of this work will be to identify the symbolic composition constructed by the entanglement of social experiences segregated by the genera that compose the territorial and everyday histories of space, creating experiences, although completely, different between men and women in the urban space.

KEYWORDS Legibility, Segregation, Territoriality.

\section{RESUMEN}

Kevin Lynch (1999) define la esencia de la experimentación de ciudad con el término "Legibilidad", que caracteriza la imagen de la ciudad por las acciones producidas a través de las experimentaciones urbanas vivenciadas en la ciudad, componiendo su sistema organizacional. Este trabajo pretende posibilitar una lectura de cómo estas experiencias se generan a través de las experimentaciones sensoriales de visión, audición, olfato y tacto, estabelecidas por Edward T. Hall (2005), que permite la concepción efectiva de la imagen específica del ambiente, incorporando así su legibilidad .

Cuando estas experimentaciones son categorizadas por la distinción de géneros, ellas proporcionan una visión diferenciada entre hombres y mujeres, como apuntados en los estudios de Beatriz Preciado (2010), pudiendo así clasificar el ambiente por su uso específico, derivado de las experimentaciones sensoriales humanas y urbanas.

Este trabajo presenta una reflexión sobre el contexto social segregado por la sexualidad, creando una fisura clasificatoria de ciudad que categoriza a quien el espacio urbano es destinado.

El objetivo de este trabajo estará en la identificación de la composición simbólica construida por el enmarañado de experiencias sociales segregadas por los géneros que componen las historias territoriales y cotidianas del espacio, creando experiencias, aunque completamente, distintas entre hombres y mujeres en el género espacio urbano apropiado.

PALABRAS CLAVE Legibilidad, Segregación, Territorialidad. 


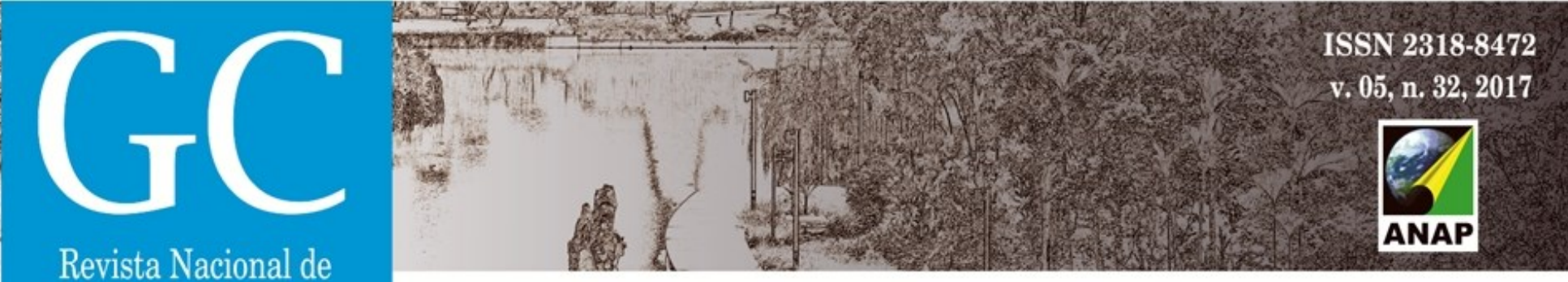

Gerenciamento de Cidades

\section{INTRODUÇãO}

As reflexões aqui abordadas partem de um principio primordial para a composição da cidade: as experiências humanas como fonte da composição do espaço urbano, sendo responsáveis pela diagramação social para o desenvolvimento do traçado da cidade. Partindo do pressuposto levantado por Beatriz Preciado (2010) que aponta que as experiências urbanas são diferenciadas por gênero e proporcionam a homens e mulheres uma imagem diferenciada de cidade, este trabalho tem a intenção de identificar como estas experiências ocorrem no espaço urbano.

Ainda, com o intuito de defender que as experiências humanas, definidas pelo gênero (e muitas vezes também pela orientação sexual), geram lugares específicos na cidade, debateremos aqui o posicionamento de autores como Michel Certeau (1998), Roger Chartier (1995) e Michelle Perrot (2017), num esforço mútuo em abordar discussões plausíveis no cruzamento das ideias de cidade, gênero e sexualidade.

O texto marca a formatação das cidades fragmentada nas relações pessoais entre cidadãos no espaço urbano. Kevin Lynch (1999. p.123) afirma que "a cidade não é construída para uma pessoa, mas para um grande numero delas, todas com grande diversidade de formação, temperamento, ocupação e classe social" e consequentemente a cidade torna-se cenário principal do espetáculo da vida, num contraste constante de características individuais, onde "são criadas pela vivacidade dos elementos e sua precisa sintonia com as diferenças funcionais e simbólicas" (LYNCH, 1999. p.122).

O desejo no aprofundamento do tema surge com os argumentos levantados na leitura do livro "Pornotopía: arquitectura y sexualidad en 'playboy' durante la guerra fría" da autora e filósofa espanhola Beatriz Preciado (2010), onde identifica as mudanças sociais ocorridas pela segregação de gênero nas cidades americanas durante a Segunda Guerra Mundial e as experiências humanas estipuladas pelas publicações da revista Playboy que, segundo a autora, geram uma nova configuração urbana.

\footnotetext{
Playboy não é apenas uma revista de conteúdos mais ou menos erótica, mas é parte do imaginário arquitetônico da segunda metade do século XX. Playboy é a mansão e seus festivais, é a gruta tropical e os jogos subterrâneos a partir dos quais os hóspedes podem observar as coelhinhas banhando-se nua na piscina através de uma parede de vidro, e a cama redonda que Hefner brinca com suas coelhas. (PRECIADO, 2010. p.15, tradução nossa) $)^{1}$.
}

\footnotetext{
${ }^{1}$ Playboy no es simplemente una revista de contenido más o menos erótico, sino que forma parte del imaginário arquitectónico de la segunda mitad del siglo XX. Playboy es la Mansión y sus fiestas, es la gruta tropical y el salón de juegos subterráneos desde el que los invitados pueden observar a las Bunnies bañándose desnudas en la piscina a través de un muro acristalado, es la cama redonda en la que Hefner juguetea con sus conejitas.
} 


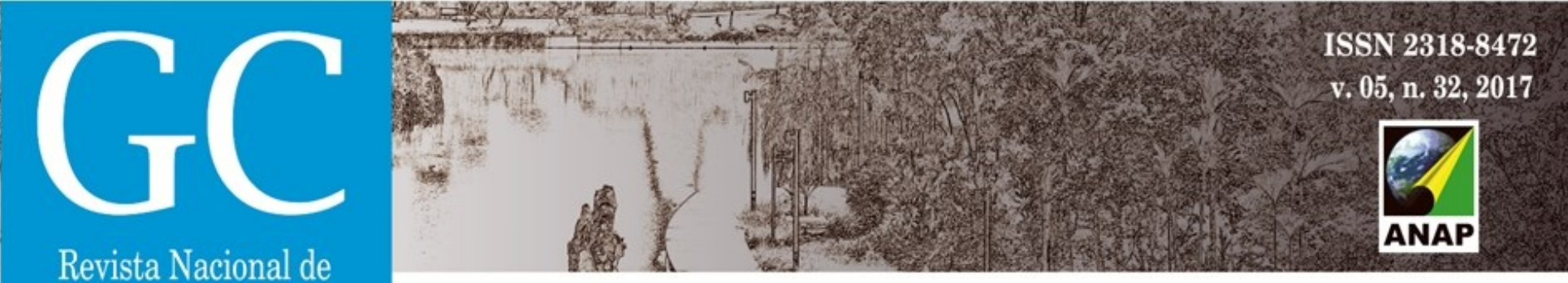

Gerenciamento de Cidades

Preciado (2010) narra à experiência de Hugh Hefner o magnata da revista Playboy, mostrando o interesse do empresário em construir uma revista além de um formato pornográfico, como uma guia enfática das experiências masculinas no contexto urbano. Sobre a imposição da experiência de gênero no meio urbano, como apontado por Preciado (2010), pretendemos apresentar a dicotomia existente entre os gêneros que fazem diferença na realização de imagem da cidade concebida pelo cidadão.

Quais são os limites de validade e os critérios de pertinência da oposição entre feminino e masculino? Roger Chartier (1995 p.38) levanta esta questão sobre a diferenciação dos gêneros e aborda esta ramificação existente entre eles, como projeto intelectual definido na história social da diferença entre os sexos, apontando que há uma formatação social partindo das diferenças sexuais. Veremos assim, a ocupação dos espaços "públicos" chefiados por uma sociedade patriarcal que dominava diretamente as experiências urbanas de trabalho, economia e política, frente a outro grupo social, o "sexo oposto" que se apresenta como "dominada", consistido em mulheres cujas experiências urbanas eram limitadas as atribuições domésticas e à família, também identificados por Perrot (2017), que tiveram suas experiências urbanas modificadas com o aparecimento do Feminismo no contexto social do pós-guerra.

Buscamos compreender o comportamento humano nas divisões sociais e de gênero centrados nas experiências sensoriais concebidas através das atividades exercidas pelo cidadão no espaço urbano, aquelas estipulados por Edward T. Hall (2005), como sensores favoráveis a concepção das experiências urbanas que constituem a imagem da cidade, exemplificado também por Arantes Neto (1994) pelo contato "a pé" numa analogia aos estudos apresentados por Certeau (1998) que estimulam um contato tátil e visual do cidadão, afim de que as experiências humanas sejam identificadas em sua particularidade e pontuadas metodologicamente, possibilitando um amplo debate sobre a formação social nas cidades, de forma que este trabalho resulte numa visão antropológica do envolvimento entre o ser humano, a sexualidade, e a cidade.

\section{EXPERIMENTANDO A CIDADE}

Legibilidade é o termo escolhido por Kevin Lynch (1999), com apontávamos acima, para definir a qualidade visual aparente da paisagem da cidade por meio de uma imagem mental definida por seus habitantes. Este conceito vincula-se à orientação estratégica da cidade estipulada no subconsciente do individuo, como um mapa mental "produto tanto da sensação imediata, quanto da lembrança de experiências passadas" (LYNCH, 1999, p.4) idealizando assim, o espaço urbano como cidade, reforçado na potencialidade das experiências humanas nela desenvolvidas. Lynch não vê a construção da cidade como um produto final, acabado e estavelmente delimitado, mas como uma contínua sucessão de fases onde a formatação urbana transcende a forma, tornando pessoas e atividades nela desenvolvidas participante da 


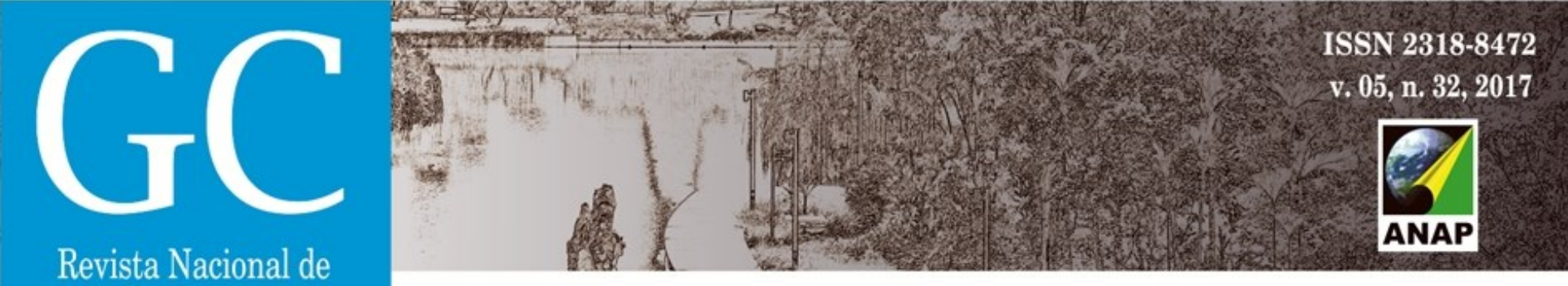

Gerenciamento de Cidades

composição da imagem perceptível da cidade, ou seja: imagem mental que produz a imagem característica da cidade.

Ainda nas ideias fundamentadas por Lynch (1999, p.2), a concepção de imagem mental da cidade formulada pelo cidadão, não está ligada a uma percepção total da cidade e sim como experiência "parcial, fragmentada e misturada a condições de outra natureza" antes vivenciada por este cidadão, tendo-as organizado e caracterizado, as imagens identificam o ambiente.

A percepção da identidade estrutural do espaço defendida por Lynch $(1999$, p.3) indicam as relações sensoriais como "capacidade vital entre todos os animais que se locomovem", sendo caracterizada "por sensações visuais de cor, forma, luz, e sentidos como olfato, audição, tato, cinestesia, gravidade e talvez campos elétricos ou magnéticos".

Esta legibilidade da cidade identificada e estipulada por Lynch através das experiências sensoriais no ambiente urbano ressalta o quão importante é a experiência humana gerada através das percepções sensoriais para composição da cidade.

Este tipo de experiência sensorial que identifica a composição espacial foi também defendido por Edward T. Hall (2005, p.50), como um sistema receptor da natureza humana, atribuindoIhe a visão, a audição e o olfato - sistema biológico que difere do sistema cultural desenvolvido pelo homem - proporcionando assim uma "percepção extremamente diferente do espaço e das relações de indivíduos no espaço".

Hall separa as experimentações sensoriais em dois grupos distintos: receptores remotos e receptores imediatos, classificando-os da seguinte forma:

1). Receptores Remotos: Composto pelas experiências decorrentes ao sistema sensorial por um contato distante entre objeto e experimentador, relacionado primeiro à audição: cujo processo de percepção eficaz do espaço se faz numa distancia até seis metros é meio (HALL, 2005. p. 52); seguido pela visão: que possibilita uma maior percepção do ambiente, podendo o cidadão captar através de seus olhos, o ambiente num raio de cem metros livres e também para interação humana, um quilometro e meio de distancia (HALL, 2005. p. 53). Por fim o olfato, definido por Hall como o último receptor remoto - diferenciado aos seres humanos em comparação a outros animais, que seguem suas necessidades biológicas - distinguindo as várias mensagens químicas exaladas que caracterizam em experiências diferentes do espaço, assimilando cultura e costumes locais aos odores perceptivos.

\footnotetext{
Na típica cidadezinha francesa, saboreia-se o aroma do café, temperos, legumes, aves recém-depenadas, roupa lavada, além do cheiro característico dos cafés ao ar livre. Esses tipos de dados olfativos podem proporcionar uma noção de que se está vivo. As mudanças e transições não ajudam a pessoa a se localizar no espaço, mas tornam estimulante a vida do dia-a-dia. (HALL, 2005. p. 62).
}

2). Receptores Imediatos: Sendo as experiências ocorridas através do sistema sensorial por um contato tangível ao objeto, relacionado ao tato. Nesse ponto, Hall identifica vários tipos de 


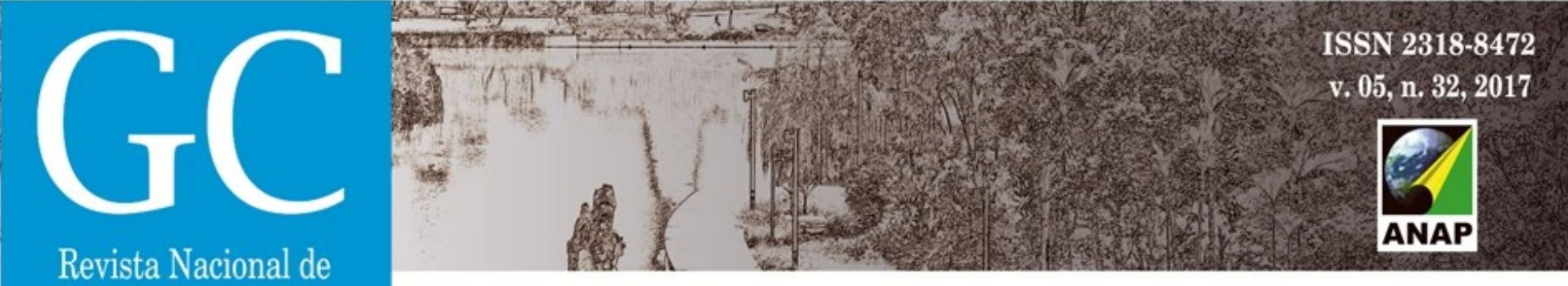

Gerenciamento de Cidades

experimentações palpáveis que proporcionam diferentes panoramas culturais e sensoriais, desempenhadas pelos fatores de necessidades espaciais no recinto: "trata-se de qualidades também relacionadas à percepção que o homem tem do espaço" (HALL, 2005. p. 67). O espaço tátil separa o observador do objeto material, possibilitando numa relação tangível a identificação de sua textura; tornando o tato a experiência mais pessoal das sensações.

Esse tipo da experiência sensorial para percepção e caracterização da imagem espacial especificada por Hall e identificada por Lynch (1999) é identitária para todos os seres ocupantes do espaço, transcendendo culturas e gêneros; tornando o espaço apropriação do uso contínuo das atividades ali desempenhadas - "estimulados ou inibidos pelo ambiente" (Hall, 2005. p.77). - transformando-o em cenário específico, consistido num elo com seu ocupante. Fazendo das experiências sensoriais humanas ali desempenhadas um mecanismo rítmico - ou como identificado por Lynch (1999), uma dinâmica repetitiva da experiência - de funcionamento gerador do sistema operacional do espaço, determinando então a identidade do lugar apropriado.

Quando a experiência foi repetida, parte da disposição do espaço - sobretudo o começo e o fim - tornam-se familiares e assumiram a característica de um lugar conhecido. (LYNCH, 1999. p. 13).

Nas palavras de Hall, a relação do homem com o ambiente está condicionada às reações geradas pelas experiências sensoriais humanas quando desenvolvidas por uma atividade específica, tendo por consequência a construção de um sistema operacional do espaço. Fazendo das experiências sensoriais humanas desempenhadas em determinado ambiente, responsáveis diretas pela definição espacial urbana, o que as tornam elementos essenciais na concepção de cidade, independente do método urbanístico adotado pelos idealizadores da cidade.

O relacionamento do ser humano com seu ambiente é uma função de seu sistema sensorial e de como este sistema está condicionado a reagir. [...] O sentido que o ser humano tem do espaço apresenta uma relação muito próxima com seu sentido de eu, que está em íntima interação com o ambiente. Pode-se considerar que o ser humano possui aspectos visuais, cinestésicos, táteis e térmicos de seu eu cujo desenvolvimento pode ser inibido ou estimulado pelo ambiente. (HALL, 2005. p.77).

Para exemplificar a estrutura de cidade, o mecanismo gerador do sistema operacional urbano classificado Jorge Wilheim (1976) é a vida. Ou seja, a movimentação das experiências humanas geradas pelas atividades desenvolvidas no espaço. "A cidade, conceituada como um organismo, dotada, portanto, de vida: uma estrutura complexa, suportando uma infinidade de atividade que a transformam constantemente" (WILHEIM, 1976. p. 57). O autor conceitua assim a estrutura da cidade como suporte a várias atividades distintas, tornando a cidade 


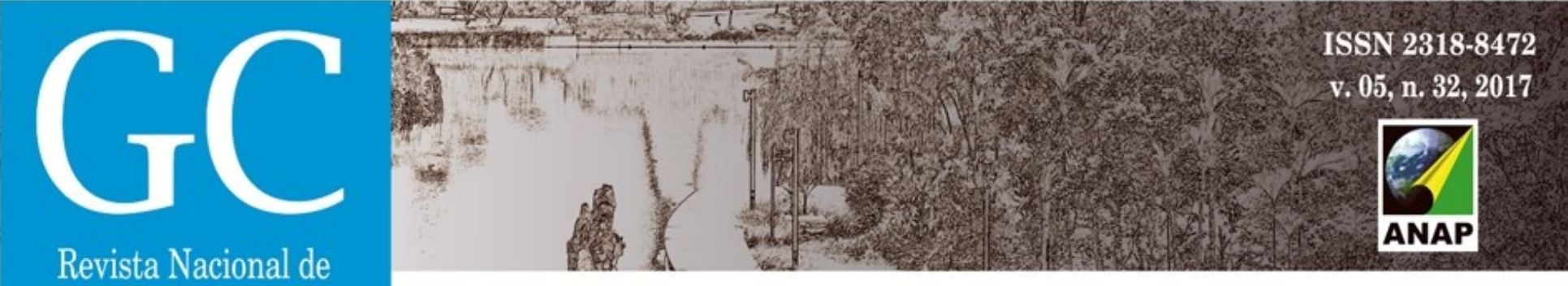

Gerenciamento de Cidades

portadora das experiências humanas variadas, criando assim inúmeras imagens elucidadas às experiências urbanas.

Pois bem, ao aceitarmos o conceito das experiências humanas como geradoras do espaço e a priori como elas são realizadas, levamos em consideração que estas experimentações territoriais são distintas e pessoais dos cidadãos, capazes de gerar visões completamente diferentes de cidade dentro do mesmo espaço urbano. Para compreensão do funcionamento das várias experiências na cidade, Wilheim (1976) estabeleceu um processo que consistia na identificação de diagnóstico e prognostico causados pelos elementos predominantes das atividades ali construídas, que são componentes significativos e substantivos do espaço.

\section{DICOTOMIA DA SEXUALIDADE: A EXPERIMENTAÇÃO URBANA DIFERENCIADA POR GÊNERO}

Dentro deste processo dinâmico da identificação das experiências de cidade estipulados por Wilheim (1976, p.65), podemos diagnosticar um sistema organizacional de cidade, "uma população formada por indivíduos que, ao nível de suas atividades cotidianas, estabelecem e recriam subsistema de vida (conjuntos de atividades de significância para a vida de cada um)".

Contudo, nenhum dos autores acima referidos conseguiu perceber a diferenciação dessas caraterísticas perceptivas sensoriais a partir da diferenciação de gênero. Foram capazes, sim, de entender que esses fatores eram fundamentais para uma aproximação mais vivida, menos tecnocrática à percepção da cidade e a sua estruturação, mas não o suficiente como para intuir que homens e mulheres vivenciam a cidade de forma distinta. Grande parte da estruturação urbana é segregada pelo gênero, sendo este um dos fatores responsáveis pela distinção entre as experiências territoriais dentro de um mesmo espaço físico, como defendido por Simões (2008), em sua analogia às ideias estipuladas por Nestor Perlongher sobre "territorialidade" ${ }^{2}$, que distribui o território urbano por códigos atribuídos ao gênero e da inclinação sexual, e também pelas ideias fundamentadas por Beatriz Preciado (2010) que estabelece um comparativo à imposição de um novo discurso sobre a masculinidade urbana desdobrada pela revista Playboy criada como o ideal do "sonho americano denominado de Disneylandia para adultos" ${ }^{\prime 3}$, entre a liberdade feminina expressada por Betty Friedan ${ }^{4}$ numa reação às normas de gênero e de segregação espacial da cidade na sociedade americana do período pós-guerra, onde Preciado (2010) explana a experiência urbana, explicando que homens e mulheres vivenciam a cidade de maneiras diferenciadas.

\footnotetext{
${ }^{2}$ PERLONGHER, Néstor. O negócio do michê: a prostituição viril em São Paulo. São Paulo: Editora Fundação Perseu Abramo, 2008.

${ }^{3}$ WATTS, Steven. Mr Playboy: Hugh Hefner and the American Dream. Nova Jersey: Wiley Hoboken, 2008. p.273 (PRECIADO, 2010. p. 17).

${ }^{4}$ FRIEDAN, Betty. La mística de la feminidad (1963). Madrid: Júcar, 1974.
} 


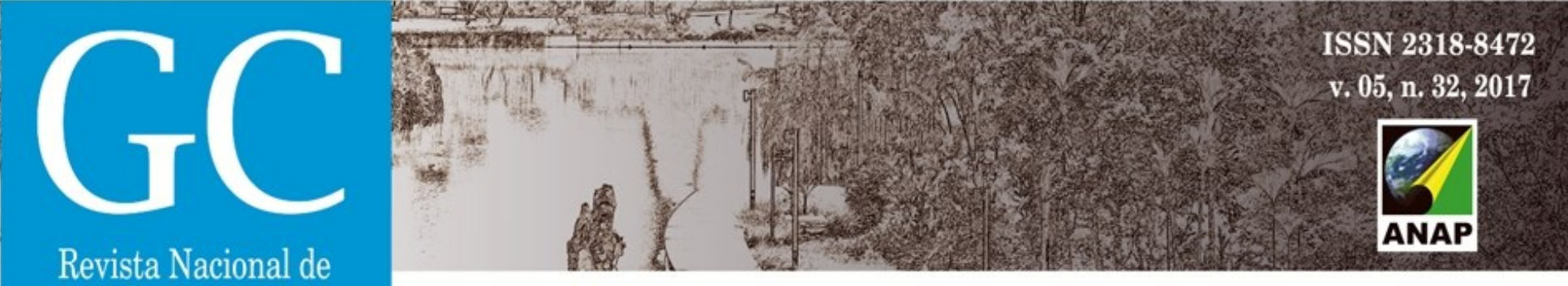

Gerenciamento de Cidades

A territorialidade é assim pensada em termos de um "código-território", que atualiza uma lógica peculiar de distribuições de atribuições categoriais corpos e desejos em movimento, estipulando a fixação a um gênero. (SIMÕES, 2008. p. 539).

A segregação urbana pode não consistir em uma barreira material, mas pode ser pensada como uma imagem mental construída pelo cidadão, ou por outros (governos, por exemplo), através de suas experiências territoriais. Wilheim (1976) afirma ao enxergar a cidade como uma "metodização" de leitura urbana perceptível, sendo possível a identificação de naturezas diversas por grupos significativos atuantes no espaço urbano, separados por classes sociais, raciais, étnicas, etária, culturais e territoriais, que o autor categoriza como "semiologia (sistemas de signos na sociedade, ritos, costumes e fenômenos culturais) da vida cotidiana" (WILHEIM, 1976. p. 64). Note-se que o autor não inclui entre as possibilidades de visões diferenciadas dessa leitura urbana a diferenciação por gênero, que em muitos casos é mais forte que a diferenciação por raça, por exemplo, pois mulheres brancas e negras sofrem, nas suas respectivas circunstâncias, os mesmos preconceitos machistas da sociedade atual. Neste caso poderíamos dizer que a condição de raça só piora as coisas quando percebemos o maior sofrimento das mulheres negras.

Numa reflexão social estabelecida pela relação entre gênero, sexualidade, desejo e território, Diego Pontes (2014) coloca em comparação os estudos de Simões (2008) fundamentado nas ideias de Nestor Perlongher, com a discussão proposta por Michel Foucault, compreendendo a sexualidade como um dispositivo histórico de poder ${ }^{5}$, relacionando ordem social à ordem sexual como elemento organizacional de diferentes experiências humanas, atribuída ao cidadão, como marca pessoal dos seus desejos, determinando assim, o espaço atribuído ao gênero.

\begin{abstract}
Desse modo, torna-se possível perceber que todo aparato [...] projetado para manutenção de estruturas e sistemas explicáveis que expressam uma "organização" social calcada no ideal binário da diferença sexual: homem e mulher, e com isso, um discurso naturalizado que aponta para uma "correspondência lógica" entre sexogênero-sexualidade-desejo, nos revela uma concepção racional de sujeitos normais, que a partir das marcas presentes em seus corpos, recebem o aval para experimentar a cidade. (PONTES, 2014. p.28).
\end{abstract}

Há tempos a sexualidade vem sido discutida como linguagem paradoxal nas sociedades humanas, o sexo cria barreiras consistentes na imagem mental que o individuo determina em sua leitura da cidade e consequentemente categoriza a área urbana observada a determinado gênero segregando-a pelo sexo. Roger Chartier (1995) ressalta fatos importantes sobre a dominação hierárquica do sexo masculino perante o feminino, quando ao fim do século XVIII era da revolução industrial francesa - a colocação da figura feminina no mercado de trabalho era submetida a uma hierarquia profissional inferior da figura masculina, atribuída pelo

\footnotetext{
${ }^{5}$ FOUCAULT, Michel. História da Sexualidade I: a vontade de saber. Rio de Janeiro: Editora Graal, 1988.
} 


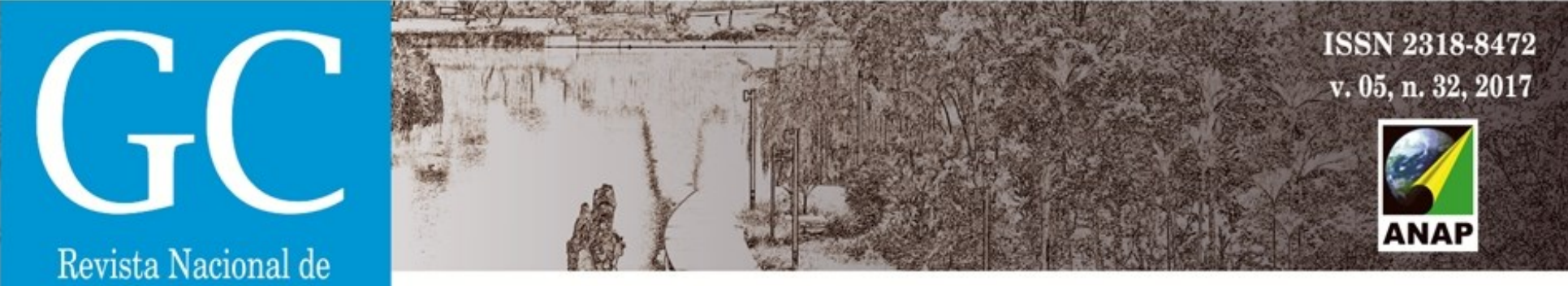

simples fato de não pertencer a atividades sociais desempenhadas no perímetro urbano destinado às experiências do gênero masculino.

\begin{abstract}
Inscrita nas práticas e nos fatos, organizando a realidade e o cotidiano, a diferença sexual (que é sujeição de umas e dominação de outros), é sempre construída pelo discurso que funda e legitima [...] Longe de ser o reflexo ou a representação das evoluções econômicas, a noção de divisão 'natural' das tarefas segundo os sexos deve então, ser considerada como um fato do desenvolvimento industrial, como uma justificação, em nome de uma definição ideal das tarefas próprias às mulheres, da condição inferior que lhes é atribuída no mercado de trabalho manufatureiro. (CHARTIER, 1995. p. 43).
\end{abstract}

Como demonstrado por Chartier à classificação do trabalho segregado no século XVIII é um reflexo das experiências humanas diferenciadas pelas atividades atribuídas ao gênero, que evidencia a existência de uma identidade territorial masculina distinta da feminina.

Quando o gênero e a sexualidade são o foco no espaço urbano, a atividade ali desenvolvida proporcionará uma experimentação de cidade diferenciadas para homens e mulheres, criando uma fissura territorial classificatória, que categoriza para quem o espaço urbano é destinado. Para António Augusto Arantes Neto $(1995$, p.4), a presença da mulher na cultura operaria inglesa "passou a enfatizar a importância tanto da variabilidade das práticas profissionais [...] quanto das diferenças e desigualdades étnicas e de gênero na formação da experiência de trabalho e, particularmente, nas concepções e práticas de tempo e espaço", o que evidencia a criação de grupos e categorias sociais segregadas pelo gênero, transformando em fronteiras sociais estabelecidas pelo desenvolvimento de seus afazeres cotidianos distintos, não por questões de grau ou intensidade, mas pela conceptualização de que todas as experiências seja por lazer, trabalho, família, etc. - são moldadas a partir de desigualdade nas relações de gênero.

Esta segregação de gêneros existente na experiência humana dita uma estruturação social urbana - como evidenciado anteriormente nos apontamentos de Simões (2008), Preciado (2010) e Pontes (2014) - e fica evidente quando o antropólogo Arantes Neto (1995) coloca em comparação as articulações da vida cotidiana e atribuições em determinadas atividades, construídas sobre as relações e desigualdades de gênero: a começar pela divisão de tempo e afazeres, onde as mulheres tendem a conceber de um modo mais flexível diversas atividades num só momento em relação ao homem, enquanto este obtém o monopólio de toda hierarquia de gêneros, fortalecido numa relação patriarcal de dominação masculina e exploração à subordinação da mulher.

Ao estereotipar as atribuições por gênero sobre as atividades desempenhadas na cidade e estabelecer o espaço masculino distinto do espaço feminino, cria-se experiências completamente distintas do ambiente. Arantes Neto (1995) também coloca a experiência humana sob um formato sexista, seguindo sempre a mesma morfologia de quando um gênero invade o espaço do outro - principalmente a mulher - "significa frequentemente desafiar 
expectativas de comportamento (e de desempenho) que são fortemente referidas a definições estereotipadas de masculinidade" (ARANTES NETO, 1995. p. 5). Fato também apresentado por Preciado (2010), que, ao estabelecer as diferentes experiências urbanas vividas pela segregação de gênero, enfatiza que até a própria arquitetura está sendo estereotipada numa encenação teatral da identidade masculina. A autora lembra que o termo "Arquitetura Playboy" foi adotado pelo historiador e crítico da arquitetura Sigfried Giedion (apud PRECIADO, 2010. p.19, tradução nossa). ${ }^{6}$ para afirmar que a arquitetura concebida no pósguerra era "uma arquitetura tratada como os playboys tratam a vida, pulando de uma sensação a outra e aborrecendo-se rapidamente". Ressalta, ainda, que a intenção da conotação "playboy" sobre a arquitetura estabelece "uma força significante de gênero, acentuando a representação da masculinidade" (2010. p.22, tradução nossa) ${ }^{7}$.

\begin{abstract}
Nesta história desenhada por Giedion, a palavra "playboy" excede a referência literal da publicação em papel para indicar uma mutação da cultura econômica americana promovida por um conjunto de consumo visual. Playboy supôs não só a transformação da pornografia na cultura da massa popular, mas também, como Giedion poderia ter adivinhado um ataque frontal ás relações tradicionais entre gênero, sexo e arquitetura. (PRECIADO, 2010. p.20, tradução nossa) ${ }^{8}$.
\end{abstract}

Preciado (2010) identifica uma ordem social baseada na "teoria das duas esferas" consolidadas numa sociedade civil do século XIX, que discutiam e argumentavam as atribuições ao espaço "público" e "privado"; e então categoriza esta divisão espacial sobre os papeis de gêneros masculinos e femininos, e classifica-os em: 1). Espaços públicos (masculinos), exteriores e políticos, onde tudo é aceitável, elegendo o homem a uma posição dominante dado pelo patriarcado estabelecido pela sociedade que "desencadeará num movimento para libertação masculina" (PRECIADO, 2010. p.33, tradução nossa) ${ }^{9}$, e 2). Espaços privados (femininos), interiores e submissos, de caráter doméstico. A sociedade moral onde "a dona de casa perfeita e o pai trabalhador são projetados como modelos de gêneros complementares que estabilizam a família branca heterossexual" (PRECIADO, 2010. p.38, tradução nossa) ${ }^{10}$.

Neste contexto vemos claramente duas distintas experimentações urbanas proporcionadas aos cidadãos (masculinos e femininos) compostas por visões completamente diferentes de

\footnotetext{
${ }^{6}$ Una arquitectura tratada como los playboys tratan la vida, saltando de una sensación a otra y aburriéndose rapidamente. (GIEDION, Sigfried, Architecture in the 1960s: Hopes and Fears. Architectural Forum, julio de 1962, vol. 117. p. 116. Trad. Castellana: Espacio, tiempo y arquitectura. Introducción La arquitetctura de los años 1960: esperanza e temores. Barcelona: Reverté, 2009. p. 18-19).

${ }^{7}$ Con la fuerza de un significante de género, acentuando la representación de la masculinidad.

${ }^{8}$ En esta historia trazada por Giedion, la palabra «playboy» excede la referencia literal a la publicación en papel para indicar una mutación de la cultura americana propiciada por un conjunto de prácticas de consumo visual. Playboy había supuesto no sólo la transformación del porno en cultura popular de masas, sino también, como Giedion quizás intuía, un ataque frontal a las relaciones tradicionales entre género, sexo y arquitectura.

${ }^{9}$ Desencadenar un movimiento por la liberación sexual masculina.

${ }^{10}$ La perfecta ama de casa y el padre trabajador son diseñados como modelos de género complementarios de los que depende la estabilidad de la familia blanca heterosexual.
} 


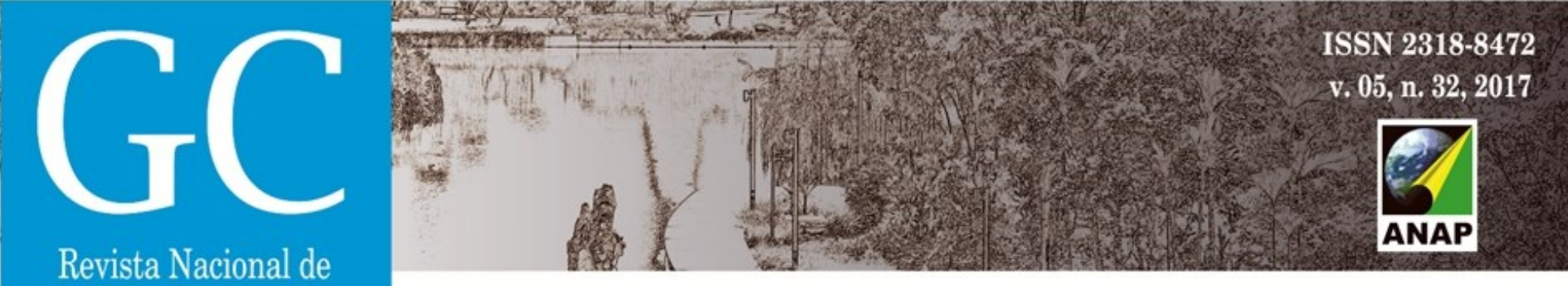

Gerenciamento de Cidades

cidade, tendo por base as experimentações sensoriais estipuladas por Hall (2005), formuladas pelas percepções espaciais captadas através da visão, audição, olfato e tato, que caracterizam então o espaço segregado pelo gênero, proporcionando uma experimentação urbana particular entre o individuo e o ambiente.

Com as diferentes experimentações urbanas elucidadas por Preciado (2010) e o espaço "público" "masculinizado" (estabelecido à especificidade das atividades masculinas a partir do momento em que o homem desenvolve estas atividades centradas em seus desejos), projetase automaticamente uma ruptura espacial, qualificando zona a simbólica masculina.

\section{A Experimentação Urbana do Gênero Dominante}

O modelo "playboy" definido por Giedion, e apresentado por Preciado (2010), é o resultado da divisão hostil do gênero dominante maior que uma divisão simbólica, materializando então o gênero no âmbito urbano. Ao homem heterossexual, branco e trabalhador pertence á dominação sobre os gêneros submissos e o monopólio das zonas qualificadas: pública e privada, classificando assim: Zona de trabalho/boêmia (urbana - zona central) e Zona Familiar (suburbana - periferia). No caso das divisões do pós-guerra apresentado por Preciado, os modelos das casas suburbanas são performativos de gênero, raça e sexualidade. "A família heterossexual branca não é apenas uma poderosa unidade econômica de produção de consumo, mas é acima de tudo a matriz do imaginário nacionalista americano" (PRECIADO, 2010. p.38, tradução nossa) $)^{11}$.

Com a propagação da cidade segregada por gênero e as experimentações urbanas centradas na satisfação dos desejos relativos à sexualidade masculina, nasce um novo tipo de homem moldado pelas publicações da revista Playboy: Um homem urbano, solteiro (ou divorciado), imprescindivelmente heterossexual, que se desloca da zona periférica familiar e se vincula integralmente à zona urbana, firmando moradia em apartamentos que se transformam em palcos para realizações tangíveis das experiências apresentadas pela periódica revista, que instiga o homem para fora do espaço domestico, trazendo um estilo de vida novo e alternativo ao modelo tradicional urbano, resultando num relacionamento diferenciado entre homem e cidade através das experiências por ele vividas, e estabelecendo assim uma nova imagem de cidade perante este gênero.

Incluindo publicações sobre a conquista e a "reapropriação" de um espaço interior ou pseudo-doméstico para o solteiro urbano: a cabana de festa glamorosa aos fins

\footnotetext{
${ }^{11}$ La familia blanca heterosexual no es únicamente una potente unidad económica de producción y consumo, sino, y sobre todo, la matriz del imaginario nacionalista americano.
} 


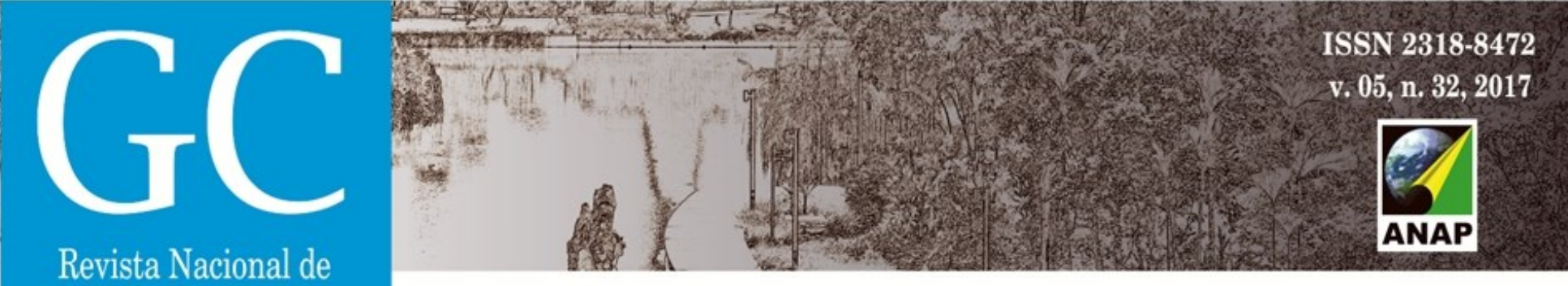

Gerenciamento de Cidades

de semana, o iate, o estúdio, a cama, o escritório ou o carro se tornam parte de um programa de reconquista (PRECIADO, 2010. p.41, tradução nossa) ${ }^{12}$.

\title{
A Experimentação Urbana do Gênero Dominado
}

A noção de público e privado que coloca o gênero masculino como dominante incide num caráter particularista, ideológico, racista e sexista, como abordado por Margareth Rago (1998. p.4), que enfatiza a divisão entre os gêneros "a partir de um conceito universal de homem, que remete ao branco-heterossexual-do-primeiro-mundo, deixando-se de lado todos aqueles que escapam deste modelo de referencia" atribuindo toda experiência dominante ao gênero masculino.

\footnotetext{
As práticas masculinas são mais valorizadas e hierarquizadas em relação às femininas, o mundo privado sendo considerado de menor importância frente à esfera pública, no imaginário ocidental (RAGO, 1998. p. 4).
}

Essa dicotomia de experiências da cidade fica clara na formatação urbana da sociedade burguesa do século XIX, apresentado por Preciado (2010), reforçando o monopólio do homem nos padrões moralistas sobre os demais gêneros, onde as experiências urbanas femininas eram até então vinculadas somente ao espaço doméstico, formadas pelas relações familiares, pela maternidade e pela troca de experiências com outras mulheres que compartilhavam do mesmo padrão social. Podemos dizer que as experiências sensoriais de visão, audição, olfato e tato femininos eram limitados ao perímetro da zona doméstica, condicionando a imagem de cidade que a mulher gerava ao ambiente familiar, impedindo que ela partilhasse das mesmas experimentações de cidade que o gênero masculino gozava. $O$ espaço doméstico se torna característico da figura feminina e moldado de acordo com suas experiências vividas.

\begin{abstract}
Esboça-se um triplo movimento no século XIX: relativo retraimento das mulheres em relação ao espaço público; constituição de um espaço privado familiar predominante feminino; superinvestimento do imaginário e do simbólico masculino nas representações femininas. (PERROT, 2017. p.180).
\end{abstract}

Já a historiadora e feminista Michelle Perrot (2017), traz o matriarcado na sociedade burguesa do século XIX, na mesma linha de pensamento de Chartier (1995), sobre um discurso trabalhista sexuado e naturalista para época, separando os gêneros em duas espécies distintas, cada qual com suas funções, papéis, e tarefas adequadas: sendo o homem o cérebro,

\footnotetext{
12 Incluirá un reportaje sobre la conquista y la reapropiación de un espacio interior o pseudo doméstico para el soltero urbano: la glamourosa cabana de fiesta para los fines de semana, el yate, el estudio, la cama, la oficina o el coche se convierten en parte de un programa de reconquista.
} 


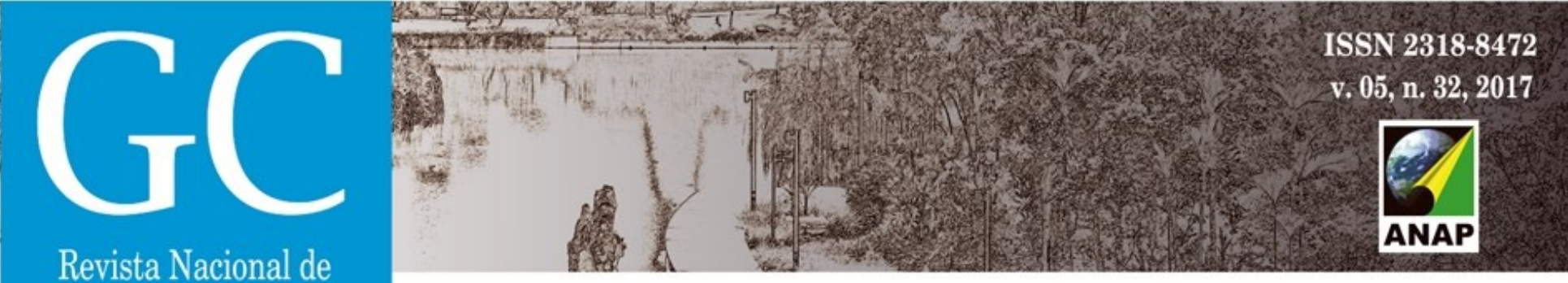

Gerenciamento de Cidades

o cidadão pensante, inteligente, apto a tomar todas as decisões, destinado ao trabalho braçal, à indústria, a politica e a burocracia do funcionamento do lar e do trabalho, enquanto a mulher era moldada por sentimentos e sensibilidade, destinada à administração doméstica, numa dinâmica delicada, carinhosa, sensível e maternal. Fazendo desses processos - que nada mais são que experiências sensoriais visíveis, auditivas, olfativas e tangíveis - em experiências urbanas diferenciadas pelo sexo, onde cada gênero é capaz de conceber uma visão diferenciada de cidade. "Ao homem, a madeira e os metais. À mulher, a família e os tecidos. Declara um delegado operário da exposição mundial de 1867" (PERROT, 2017. p.187).

Segundo Perrot (2017) as mudanças progressistas que aconteceram na sociedade industrial também alteraram o discurso feminino, tornando a mulher a base da família, exercendo dentro do lar uma "autoridade preponderante" moldada num "falso matriarcado", onde a autonomia de sua soberania continuara submissa à figura masculina, não ultrapassando as margens domésticas, sendo ainda excluídas dos espaços públicos junto aos proletários.

Este movimento feminista aparece sem muitas forças auferidas, na qual as mudanças acarretadas por sua potencia ganham lugar gradativamente nos espaços "públicos" de domínio elementar do patriarcado, moldando aos poucos a imagem da cidade através das experiências urbanas vivenciadas pela mulher. A mulher tida como "símbolo de uma divindade do santuário doméstico" (PERROT, 2017. p. 188), conquista cada vez mais o espaço público, agindo do lar para a cidade. Cabia à mulher a alfabetização dos filhos, destinando-as assim geralmente ao desenvolvimento de instituições hospitalares e escolares. "A presença das mulheres, tão fortes nas ruas do século XVIII, persiste na cidade do século XIX, onde elas mantêm circulações do passado, cercam espaços mistos, constituem espaços próprios" (PERROT, 2017. p.189).

As novas experiências de cidade concebidas com a inserção da mulher nos espaços públicos deram oportunidades ao desenvolvimento feminista século XX, criando a "mulher emancipada que reivindica a igualdade dos direitos civis e políticos, o acesso às profissões intelectuais e recusa, justamente, confinar-se à 'vocação' materna” (PERROT, 2017. p.189), reivindicadas inicialmente pelas mulheres russas na Revolução de Outubro em 1917, quando a Primeira Guerra causou um grande impacto da "feminização" na classe operária devido à mobilização dos homens ao exército. Mulheres eram oneradas como trabalhadoras e mães/esposas, ressalta Danielle Jardim da Silva (2017) através dos dados levantados por Leon Trotsky ${ }^{13}$, especificando um motim de mulheres operárias mobilizadas numa grande greve em protesto por igualdade legal das mulheres, plenos direitos civis, políticos, legislação progressista sobre a família, inserção das mulheres no trabalho assalariado e iniciativas de socialização do trabalho doméstico e proteção à maternidade, libertando assim as mulheres da obrigatoriedade do cuidado do lar, incluindo-as em participações políticas, culturais e sociais. "Na manha do dia 23 de fevereiro as mulheres das fabricas têxteis do distrito de Vyborg cruzaram os braços e saíram

${ }^{13}$ TROTSKY, Leon. História da Revolução Russa. 2ed. Rio de Janeiro: Paz e Terra, 1977. 


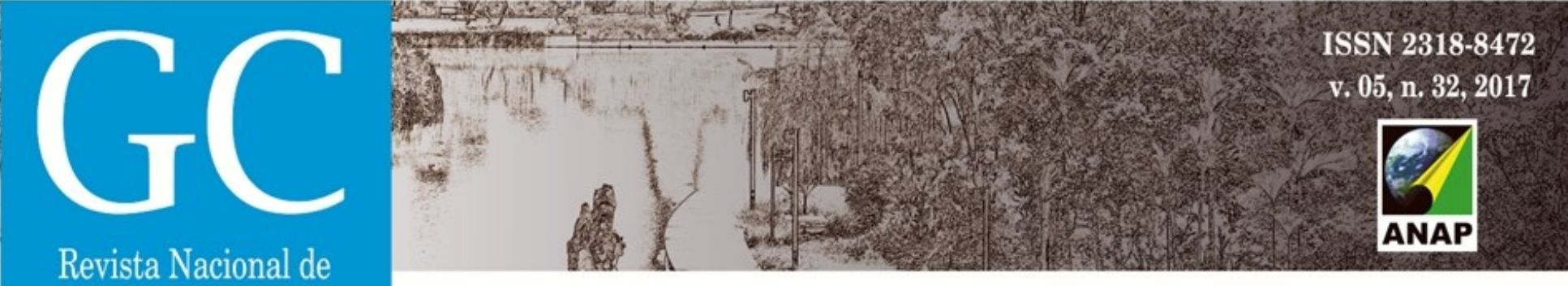

Gerenciamento de Cidades

pelas ruas em busca de adesões. Munidas de pedras, elas paravam a frente das fábricas". (SILVA, 2017. p.4).

As reivindicações do movimento feministas como apresentadas por Silva (2017) foram atendidas e em outubro de 1918, com isso a família patriarcal é destruída na Rússia e um Código Completo de proteção feminina ao Casamento, à Família e à Tutela é instaurado.

\begin{abstract}
A ideia por de trás dele era o reconhecimento da mulher como cidadã de plenos direitos, e a família como união entre iguais, baseada no respeito e no amor mútuo. Dessa forma, a lei aboliu o poder marital, impedindo o marido de impor o nome, domicilio ou nacionalidade à esposa, instituiu a pensão alimentícia em caso de separação e acabou com a diferença entre filhos legítimos e ilegítimos. Além disso, o trabalho feminino também foi protegido e foi criada a licença-maternidade. (GOLDMAN, 2014. p.71-74, apud SILVA, 2017. p.7) ${ }^{14}$.
\end{abstract}

Assim como na Rússia, além da inserção da mulher no mercado de trabalho, Preciado (2010) também pontua a ida dos homens em massa aos campos de batalha na Segunda Guerra Mundial como divisor da segregação espacial urbana por gênero nas cidades americanas, tornando a mulher do século XX fortemente integradas na vida pública e ao trabalho produtivo fora do espaço doméstico, complicando a noção de "interior" e "exterior", categorizados como espaços "femininos" e "masculinos", dando margens a uma nova experimentação de cidade.

\title{
3. A MORFOLOGIA DA CIDADE SEGREGADA POR GÊNERO
}

Os espaços públicos das cidades americanas apresentados anteriormente por Preciado (2010) caracterizam o cenário da cidade pós-guerra tendenciados pelas experiências mistas de gêneros desenvolvidas pela igualdade da sexualidade. O olhar pela cidade e a formação da imagem do espaço urbano ganham novas proporções ao possibilitar experimentações universais aos cidadãos. Não que a segregação esteja acabada, e sim ramificada na divisão da sexualidade, possibilitando a inclusão dos gêneros dominados nos espaços urbanos onde eram característicos do gênero dominante, colocando em risco a ordem espacial heteronormativa. ${ }^{15}$ Sobre o estudo fundamentado de Arantes Neto (1995), Diego Pontes (2014) defende uma sociedade separada sexualmente e dominada hierarquicamente por um gênero dominante, organizando-se segregadamente sobre uma barreira moral, onde a relação dos corpos diversos ao espaço caracteriza a estrutura da cidade em identidade própria, dando-lhe um novo formato, quando gêneros diversos invadem os espaços urbanos destinados ao homem-

${ }^{14}$ GOLDMAN, Wendy. Mulher, Estado e Revolução: política familiar e vida social soviéticas, 1917-1936. São Paulo: Boitempo, 2014

15 Heteronormativos: Refere-se à heteronormatividade, ao conceito de que apenas os relacionamentos entre pessoas de sexos opostos ou heterossexuais são normais ou corretos. Que enxerga a heterossexualidade como a norma numa sociedade. [Por Extensão] Que marginaliza as orientações sexuais que diferem das heterossexual. Disponível em < www.dicio.com.br > Acesso em: 30 de Set. 2017, 18:00:00. 


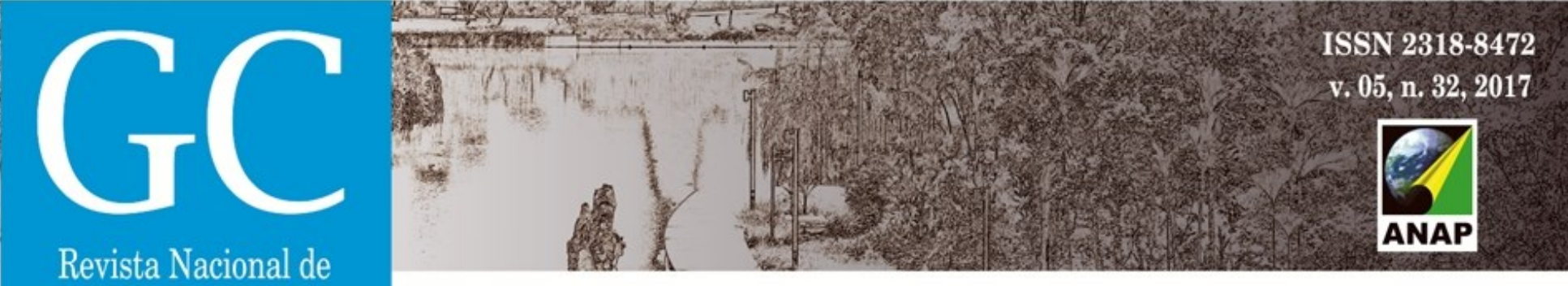

heterossexual-branco-trabalhador e vivenciam novas experimentações da cidade, formando assim novas imagens do espaço urbano.

\begin{abstract}
Os debates atuais acerca das relações de gênero e sexualidade e antropologia urbana ou arquitetura e urbanismo críticos, colocam em evidência a fragmentação e as negociações dos corpos com os espaços das cidades. O gênero e a sexualidade enquanto marcadores classificatórios e sociais da diferença na experimentação da cidade, além de fomentar olhares, a partir dos discursos e práticas sobre como homens e mulheres são apresentados à cidade e como a experimentam, me levam a reconhecer que mesmo com a segregação urbana heteronormativa, setorização e higienização dos espaços urbanos, brechas e fissuras são abertas; a cidade é reapropriada e ressignificada cotidianamente, desorientando a forma que a encaramos e o modo de nos compreendermos dela (PONTES, 2014. p.31).
\end{abstract}

A cidade dicotomizada pelo gênero proporciona aos cidadãos uma experimentação urbana capaz de moldar seu próprio espaço público, sendo possível a identificação da imagem característica da cidade pela troca de experiências sensoriais realizadas através das experiências nela desenvolvidas. Michel de Certeau (1998) apresenta uma experimentação sensorial de cidade como sistema prático de apropriação do espaço de ordem construída, onde o cidadão é capaz de identificar a imagem da cidade pela experiência sensorial tangível de caminhar a pé pelo perímetro urbano. De acordo com o autor, a experimentação da cidade neste processo de apropriação topográfica em escala humana dada pelo "pedestre" cria um sistema real de identificação de movimentação da cidade e de suas táticas cotidianas, possibilitando o individuo a extrair fragmentos de uma ordem espacial que organiza um conjunto de possibilidades, sendo a identidade da cidade uma composição simbólica de um emaranhado de experiências sociais que compõe sua historia e seu cotidiano.

Os demonstrativos dizem do visível suas invisíveis identidades: constitui a própria definição de lugar, com efeito, se esta série de deslocamentos e de efeitos entre os estratos partilhados que o compõe e jogar com essas espessuras em movimento (CERTEAU, 1998. p.189).

Essa troca de experiência sensorial do deslocamento feito pelo caminhar na cidade sendo capaz de moldar o espaço, é colocada tanto por Pontes (2014) e pelo antropólogo Arantes Neto (1994) numa analogia aos estudos apresentados por Certeau (1998) como marcos visíveis que perduram lugares de identidade constituídas na sucessão das atividades cotidianas trabalho, o lazer e a vida - capazes de reconfigurar o lugar apropriado pelos corpos, articulados no tempo e no espaço.

Nessa direção, as afetividades urbanas cotidianas que embaralharam as noções de lugar e tempo das ruas, apontam para caminhos distantes dos códigos-espaçoscorpos-ritmos do tempo e do lugar sagrado da família. Não há tempo e lugar fixo que organize o espaço e o corpo. Borram-se as fronteiras das margens, do centro e da 


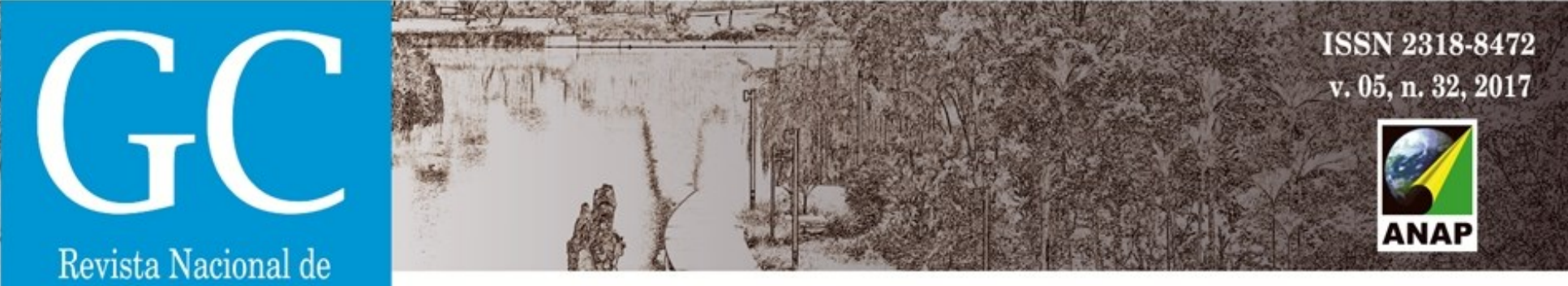

Gerenciamento de Cidades

periferia, do publico e do privado, reconfigurando, desse modo, as experimentações e o exercício da arquitetura do espaço público. (PONTES, 2014. p.26).

Cria-se assim uma apropriação do espaço urbano de comunicação ao alcance do pedestre, como exemplificado por Arantes Neto (1994), isso acontece quando o cidadão ao caminhar exerce um domínio sobre topografia urbana, constituindo lembranças do trajeto, numa experimentação particular de cidade, recolhendo fragmentos de historias e do lugar pela sua atuação no espaço em relação à movimentação urbana.

\section{CONSIDERAÇÕES FINAIS}

O espaço da cidade que conhecemos hoje mantém um sistema estrutural produto das relações sociais, que vai muito além do planejamento urbano, ainda que este seja uma condicionante importante. Devemos dar respaldo total às experiências sensoriais que são capazes de formatar a cidade segundo as atividades nela desempenhadas, deixando o desenvolvimento da cidade à mercê de seus experimentadores, onde a esfera social, embasada nas experiências urbanas, deveria entrar como fator essencial, do planejamento urbano, que por sua vez, deveria ser condizentes com a mobilidade que a apropriação dos corpos (dos cidadãos) faz do espaço público.

Fica evidente neste estudo que por muito tempo se negligenciou a importância da definição de gênero para pensar a cidade, praticamente foi necessário esperar até finais do século XX para que pesquisadores (e pesquisadoras) reivindicassem está particularidade como uma importante modalidade diferenciadora do entendimento da cidade, e de sua construção e uso. As categorias de gênero, assim como as preferências sexuais, da população foram sempre determinantes da formação de partes importantes, ainda que marginalizadas, da cidade. As zonas vermelhas e as áreas de prostituição e vício destinadas à vida boemia foram por séculos dominados por homens, porque para eles eram destinadas. A mudança desses hábitos no final do século XX levou primeiro, homossexuais e, depois mulheres a integrasse nesse mundo de diversão e sexo. O flagelo do AIDS mudou a perspectiva nos anos 1980 e 1990, porque um importante esforço higienista (anti feminino e homofóbico) destruiu a construção libertária posterior ao movimento hippie e o feminismo dos anos 1960. Hoje nos enfrentamos a outra situação, confusa ainda, para a qual talvez seja importante recuperar estas visões de sensibilização humana, por gênero, que evidenciem forma sociais mais justas de compartilhar o espaço público da cidade.

\section{REFERÊNCIAS BIBLIOGRÁFICAS}

ARANTES NETO, António Augusto. A Guerra dos Lugares: Sobre Fronteiras Simbólicas e Liminaridades do Espaço Urbano. Revista do Patrimônio Histórico e Artístico Nacional. Rio de Janeiro, BR: Revista do IPHAN, no23 1994. 
Disponível em < http://docvirt.com/docreader .net/DocReader.aspx?bib=reviphan\&pagfis=8522 > Acesso em: 30 de Set. 2017, 16:00:00. 191-204p.

ARANTES NETO, António Augusto. Horas Furtadas: Ensaio sobre o Consumo e Entretenimento. Coimbra, PT: Oficina do CES Centro de Estudos Sociais, no42, 1995. Disponível em < http://www.ces.uc.pt/publicacoes/oficina/ ficheiros/42.pdf> Acesso em: 30 de Set. 2017, 16:00:00. 50p.

CERTEAU, Michel. A invenção do Cotidiano. 3ed. Petrópolis, RJ: Editora Vozes, 1998. 351p.

CHARTIER, Roger. Diferenças entre os sexos e dominação simbólica. Cadernos PAGU, no.4, Unicamp, São Paulo, p. 37-47, 1995.

HALL, Edward T. A Dimensão Ocult; tradução Waldéa Barcellos. São Paulo: Martins Fontes, 2005. 258p.

LYNCH, Kevin. A imagem da Cidade; tradução Jefferson Luiz Camargo. São Paulo: Martins Fontes. 1997. 227p.

PERROT, Michelle. Os excluídos da história: operários, mulheres e prisioneiros. 7ed. Rio de Janeiro/São Paulo: Paz\&Terra, 2017. 362p.

PONTES, Diego. A insustentável arquitetura dos corpos: $\mathbf{O}$ gênero e a sexualidade enquanto diferenciais na experiência urbana. Florianópolis, SC: 2014. Disponível em < https://repositorio.ufsc.br/xmlui/bitstream/handle/ 123456789/123800/TCC_Diego\%20Pontes\%20PDF_A5_originapdf?sequence=1\&isAllowed=y> Acesso em: 25 de Set. 2017, 01:25:00. 69p.

PRECIADO, Beatriz. Pornotopía: arquitectura y sexualidad en Playboy durante la guerra fría. Barcelona: Editora Anagrama, 2010. 95p.

RAGO, Margareth. Epistemologia Feminina, Gênero e História. In: Pedro, Joana; Grossi, Miriam (orgs) - Masculino, Feminino, Plural. Florianópolis, SC: Ed. Mulheres, 1998. Disponível em < http://projenpq.mpbnet.com.br/textos/ epistemologia_feminista.pdf> Acesso em: 30 de Set. 2017, 15:00:00. 17p.

SILVA, Danielle Jardim da. Feminismo e revolução: a questão das mulheres na Revolução de Outubro, no governo soviético e no pensamento de seus intelectuais. Rio de Janeiro: PPGH/UFF, 2017. Disponível em < http://www. niepmarx.blog.br/MM2017/anais2017/MC13 /mc131.pdf> Acesso em: 09 de Out. 2017, 14:00:00. 20p.

SIMÕES, Julho Assis. O negócio do desejo. Cadernos PAGU, São Paulo, p. 535-546, 2008.

WILHEIM, Jorge. O Substantivo e o Adjetivo. São Paulo: Perspectiva. 1976. 229p. 